\title{
Lifestyles in suburban populations: A systematic review
}

\author{
Samira Khayat ${ }^{1}$, Mahrokh Dolatian ${ }^{2}$, Ali Navidian ${ }^{3}$, Zohreh Mahmoodi ${ }^{4}$, Nasibeh Sharifi ${ }^{5}$, Amir Kasaeian ${ }^{6}$
}

${ }^{1} \mathrm{Ph} . \mathrm{D}$. Student in Reproductive Health, Department of Midwifery and Reproductive Health, International Branch, Shahid Beheshti University of Medical Sciences, Tehran, Iran

${ }^{2}$ Assistant Professor, Department of Midwifery and Reproductive Health, School of Nursing and Midwifery, Shahid Beheshti University of Medical Sciences, Tehran, Iran

${ }^{3}$ Associate Professor, Department of Nursing, Community Nursing Research Center, Zahedan University of Medical Sciences, Zahedan, Iran

${ }^{4}$ Assistant Professor, Non-communicable Disease Research Center, Alborz University of Medical Sciences, Karaj, Iran

${ }^{5} \mathrm{Ph} . \mathrm{D}$. Candidate of Reproductive Health, Student Research Committee, School of Nursing and Midwifery, Shahid Beheshti University of Medical Sciences, Tehran, Iran

${ }^{6}$ Assistant Professor, Hematology-Oncology and Stem Cell Transplantation Research Center, Tehran University of Medical Sciences, Tehran, Iran

Type of article: Systematic review

\begin{abstract}
Background: Lifestyle and suburban population are important issues in the field of health. The living conditions of informal settlements can lead to acquisition of an unhealthy lifestyle.

Objective: This study has been designed to investigate the articles that have been published regarding lifestyle in suburban populations.

Methods: The present research was a systematic review of studies in databases including Iranmedex, Magiran, SID, Irandoc, PubMed, Google Scholar, Science Direct and Scopus, in 2017. All Persian and English papers written from 2000 to 2017 were evaluated by two reviewers using an advanced search of the databases with keywords related to lifestyles and suburban population. After completion of the search, the Strengthening the Reporting of Observational Studies in Epidemiology (STROBE) checklist was used to evaluate the articles.

Results: In total, 19 articles were found to have addressed the lifestyle in suburban populations. The results of these studies showed an unhealthy lifestyle in the most informal settlements. There was no food diversity. Malnutrition was common, especially overweight. The majority of the people did not have enough physical activity, and smoking and alcohol consumption were common, especially in men.

Conclusion: Studies showed that suburban populations are among the groups that have unfavorable environmental conditions to acquiring healthy lifestyle and maintaining appropriate health. Therefore, developing infrastructure, improving health services (environment, treatment of diseases, reduction of malnutrition and infant mortality, access to safe drinking water and sanitation, improving waste disposal and recycling it), improving education and smoking prevention programs in improving lifestyle is recommended.

Keywords: Suburban population, Poverty area, lifestyle, Systematic Review
\end{abstract}

\section{Introduction}

Lifestyle refers to the way of living that an individual chooses during life (1) and it is taken into account as an indicator of physical and mental health (2). A variety of definitions have been proposed for lifestyle. In general, lifestyle is associated with individual styles in routine life, and includes different factors such as personality traits,

\section{Corresponding author:}

Mahrokh Dolatian, Department of Midwifery and Reproductive Health, School of Nursing and Midwifery, Shahid Beheshti University of Medical Sciences, Tehran, Iran.

Tel.: +982188202517, Fax: +982188202517, Email: mhdolatian@gmail.com

Received: January 08, 2017, Accepted: June 12, 2017, Published: July 2017

iThenticate screening: May 10, 2017, English editing: July 02, 2017, Quality control: July 12, 2017

(C) 2017 The Authors. This is an open access article under the terms of the Creative Commons Attribution-NonCommercialNoDerivs License, which permits use and distribution in any medium, provided the original work is properly cited, the use is non-commercial and no modifications or adaptations are made. 
nutrition, physical activity, sleeping habits, coping with stress, social support, and use of medications $(3,4)$. In this regard, the World Health Organization (WHO) has defined lifestyle as the distinctive patterns of behavior formed through interaction between personality traits, social relationships, environmental conditions, and socioeconomic status (5). Currently, health professionals consider lifestyle as one of the most important factors affecting health; thus, studies have shown that more than $70 \%$ of illnesses such as cardiovascular diseases, respiratory disorders, motor-system and muscular problems and the like are directly or indirectly correlated with lifestyle $(2,6)$. As a result; controlling improper lifestyles distinguished via poor nutrition, lack of exercise, smoking, and alcohol consumption can lead to a reduction in illnesses and mortality (7). Suburban populations are among the groups influenced by inappropriate environmental conditions in terms of their lifestyles and health maintenance. Informal settlement is considered as a global and pervasive problem which can be abundantly observed in developing countries as well as developed ones (8). Over recent decades, unorganized neighborhoods and informal settlements mainly on the outskirts of large cities have been shaped and expanded across Iran. According to the latest statistics released, the population of informal settlers in Iran has increased to approximately 10.3 million people (9). Such informal settlements are characterized by poverty, illiteracy, illegal and low-income jobs, as well as poor living conditions. Thus, the existing socioeconomic conditions hinder choosing healthy lifestyles for this group of society (10). In general, inappropriate lifestyles (including employment conditions, nutrition, and physical activities) have been raised as influencing factors leading to death and diseases among suburban populations (11) who are stricken by poverty, the majority of whom are living in conditions below the poverty line $(12,13)$. Residents in such informal areas also suffer from ill-health asymmetry throughout lifetime. Such individuals experience higher rates of illnesses, injuries, and premature death (14). Living on the margins of cities similarly leads to premature aging and a range of chronic diseases including high blood pressure, arthritis, diabetes, and headache (15-17). However, having a healthy and high-quality lifestyle coupled with acceptable lifetime with no diseases or disabilities is taken into account as universal rights and preconditions to achieve sustainable development $(18,19)$. Suburban populations are encountered by numerous challenges in their life-time including economic, social, educational, and health-related ones, of which consequences are not limited to this stratum of society, and can have impacts on an entire community (20-22). As a result, the negative consequences of informal settlements are creating burdens for officials which affect health and welfare in individuals, families, and societies (21). Worldwide, there have been numerous isolated studies conducted on lifestyle of suburban populations and each study has addressed the different dimensions of lifestyle. But, those results have not been summarized in one place. Given the importance of lifestyle among informal settlers, its understanding can be helpful in its reformation and reduction of health problems. Considering the problem of informal settlers is growing across the world including Iran, also, the significance of lifestyle in all health dimensions, and lack of a comprehensive review on lifestyles in informal settlements; a review study is essential to understanding the problems and challenges in suburban populations, and designing further research and programs to improving their health. So, the present study was to investigate lifestyle among suburban populations.

\section{Material and Methods}

The present study was a systematic review. The findings of this study were obtained from investigations carried out in Iran and other countries as published research studies indexed in databases such as Iranmedex, Magiran, SID, Irandoc, Scopus, Science Direct, PubMed, and Google Scholar. The present study was conducted in several steps including determination of problem of study (problem statement), data collection, and interpretation of findings. To this end; at first, studies were collected based on their titles and then on the basis of keywords and operators of "and" and "or". To limit the data, key words and phrases (suburban, suburbia, suburbanization, slum, informal settlements, lifestyle, nutrition, food consumption, smoking, alcohol, physical activity, sports, leisure, body mass index) were used in this regard. In this study, all Farsi and English studies published between 2000 and 2017 were investigated. Identifying and evaluating the studies were conducted by Preferred Reporting Items for Systematic Reviews and Meta-Analyses (PRISMA) (23-24) flow diagram by two reviewers (Figure1). At first, the researchers collected the published studies associated with lifestyles in informal settlements in Iran and other countries, and then a list of abstracts was prepared. After the removal of author and journal information, the full-text studies were submitted to the reviewer. If a study was rejected, the reasons for its refusal were highlighted. In the next step, the studies were investigated based on inclusion and exclusion criteria in order to select the best ones. Inclusion criteria observed were: (1) full-text papers written in English or Persian that covered every dimension of lifestyle, (2) observational studies (cross-sectional, case-control, and cohort studies), and (3) studies with sample sizes $\geq 50$ people. Exclusion criteria observed were (1) papers irrelevant to the topic, (2) data pertaining to review papers, case reports, abstracts, posters, theses and letters to the editor, (3) reporting repeated results from other papers. The final evaluation of the studies was quality assessment which was conducted through STROBE checklist for crosssectional studies. STROBE checklist contains 22 items (25) and includes research title, year and place of study, 
sampling method, sample size and type of study. Quality assessment was conducted by two reviewers. The questions were answered by yes $($ score $=1)$ and no $($ score $=0)$. Maximum score was 30 . For each study, score $\geq 15$ were considered as good quality and conditions of entry to final review. Categorization of studies in terms of their subjects was shown in Figure 1. Using thirteen keywords in combination or individually, 36 studies were obtained by eliminating irrelevant ones or those with duplicate results; out of which, 31 studies were selected and evaluated based on inclusion and exclusion criteria and STROBE checklist, then, twelve studies were excluded. Finally, nineteen research studies were examined.

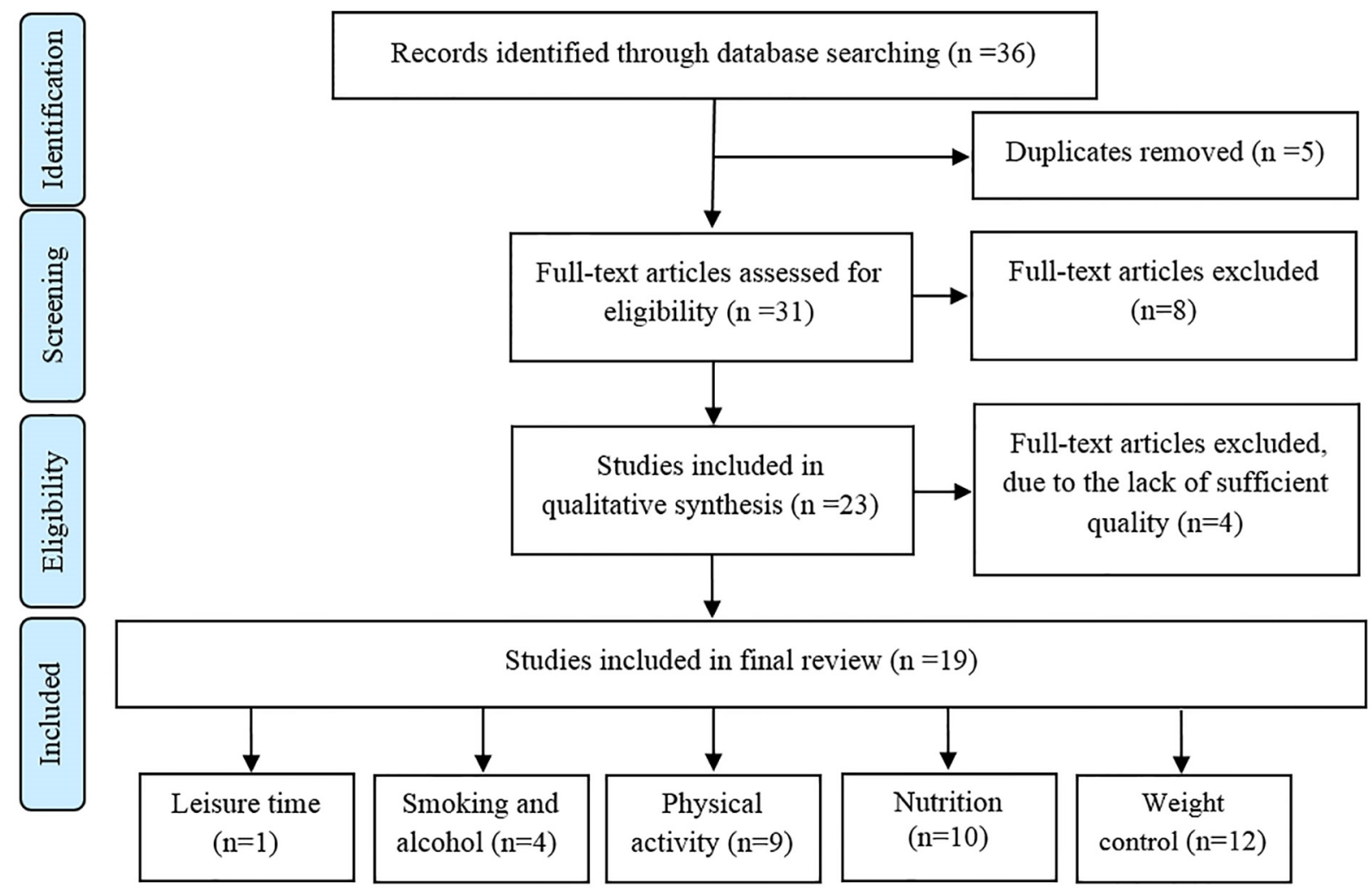

Figure 1. PRISMA flow diagram of review process.

\section{Results}

There were limited studies in terms of health and lifestyle among informal settlers, and the studies conducted in this regard were from countries such as India (7 articles), Kenya (1 article), Bangladesh (1 article), Brazil ( 2 articles), Nigeria (1article), Peru (1article), Nepal (1article), South Africa (1article), and Iran (3 articles). In this systematic review, all the studies reviewed were cross-sectional descriptive (5 articles) and descriptive-analytic (14 articles). Out of the 19 papers reviewed, 12 studies had examined weight control and body mass index (BMI), 10 studies were on food intake, 9 investigations were associated with physical activity, 4 articles were related to tobacco and alcohol consumption, and 1 study had assessed leisure time activities among informal settlers. Results were chronologically summarized in Table 1 from the recently published papers to the previous ones. According to Table 1, the results of most studies examining nutritional status among informal settlers indicated low protein intake, low fruit and vegetable consumption, and high intake of salt; so that less than $20 \%$ of these individuals had protein intake $(26,27)$ and $90 \%$ did not have fruit and vegetables $(26,28,29)$. In terms of examining BMI, some studies reported overweight and obesity; for example, $57.1 \%$ of informal settlers in Mumbai suffered from abdominal obesity (30), $75 \%$ of slum dwellers in Bangalore in India were affected with obesity (31), and $21.7 \%$ and $35.7 \%$ of residents living in informal settlements in Hyderabad in India had overweight or obesity and abdominal obesity respectively (26). In this regard, 53\% of informal settlers in Peru suffered from obesity and overweight and 54\% of women had abdominal obesity (32). In the slum areas in Nairobi in Kenya, $43.3 \%$ of women and $17.3 \%$ of men were affected with overweight or obesity (33). In Nepal, $26 \%$ of male and $23.9 \%$ of female residents in informal settlements were also suffering from overweight (28). In addition, underweight $\left(\mathrm{BMI}<18.5 \mathrm{~kg} / \mathrm{m}^{2}\right)$ was reported from $7.1 \%$ in informal settlers in Mumbai to $23 \%$ in eight mega-cities in India $(30,34)$. Considering physical activity, $84 \%$ of 
slum dwellers in Bangalore (31), 92.1\% of informal settlers in Mumbai (30), 53.6\% of individuals living in informal neighborhoods in Hyderabad (26), 39.4\% of women in slum areas in Kathmandu (28), 64.7\% of women residing in informal settlements in the city of Kermanshah (35), 17\% of women living in Recife (36), 26.1\% of informal settlers in Brazil (37), and 61\% of individuals living in informal settlements in Columbia did not do appropriate physical activities (38). Taking smoking and alcohol consumption into account, 35\% of men and 4\% of women in informal settlements in Peru had used alcohol and 34\% of men and 8\% of women had experienced smoking cigarettes (32). Fifteen point four percent of tobacco use and 19.5\% of alcohol consumption was also reported among informal settlers in Hyderabad (26). In Nepal, $58 \%$ of men and $24.9 \%$ of women living in informal settlements had alcohol consumption and $51.9 \%$ of men and $24.1 \%$ of women had experienced smoking (28). In addition, $1.4 \%$ of female informal settlers in the city of Kermanshah had also experienced smoking (35).

Table 1. Details of the studies conducted on dimension of lifestyles in informal settlements

\begin{tabular}{|c|c|c|c|c|}
\hline $\begin{array}{l}\text { Ref. } \\
\text { no. }\end{array}$ & Foodstuff Intake & Sports and Leisure Time & $\begin{array}{l}\text { Smoking \& Alcohol } \\
\text { Consumption }\end{array}$ & $\begin{array}{l}\text { Study } \\
\text { quality }\end{array}$ \\
\hline 31 & $\begin{array}{l}\text { Daily salt intake in } 39 \% \text { of respondents } \\
\text { was more than } 5 \text { grams }\end{array}$ & $\begin{array}{l}\text { Overall, } 84.8 \% \text { of individuals had } \\
\text { sedentary lifestyle, } 13.4 \% \text { of these } \\
\text { informal settlers did light exercises, } \\
\text { and } 1.8 \% \text { of them did a moderate level } \\
\text { of physical activities }\end{array}$ & & 24 \\
\hline 64 & & $\begin{array}{l}\text { In total, } 61.7 \% \text { of women had face-to- } \\
\text { face relationships, } 49.6 \% \text { of these } \\
\text { settlers did unplanned physical } \\
\text { activities, } 32.1 \% \text { of them did fun } \\
\text { activities; } 26.8 \% \text { of these individuals } \\
\text { practiced religious activities, } 13.9 \% \text { of } \\
\text { them did physical activities, } 5.2 \% \text { did } \\
\text { artistic activities, and } 2.6 \% \text { had taken } \\
\text { training courses }\end{array}$ & & 29 \\
\hline 35 & & $\begin{array}{l}\text { In total, } 29.2 \% \text { did no physical } \\
\text { activities, } 35.5 \% \text { of them did physical } \\
\text { activities at very low levels, and } \\
18.4 \% \text { of these settlers did a moderate } \\
\text { level of physical activities, and } 2.2 \% \\
\text { did high levels of sports }\end{array}$ & $\begin{array}{l}\text { In total, } 1.4 \% \text { of informal } \\
\text { settlers were smoking }\end{array}$ & 28 \\
\hline 32 & & & $\begin{array}{l}\text { Overall, } 35 \% \text { of men and } \\
4 \% \text { of women consumed } \\
\text { alcohol, } 34 \% \text { of men and } \\
8 \% \text { of women were } \\
\text { smokers }\end{array}$ & 30 \\
\hline 30 & & $\begin{array}{l}\text { Overall, } 7.9 \% \text { of these individuals did } \\
\text { physical activities in their life routines } \\
\text { and } 92.1 \% \text { did not exercise }\end{array}$ & & 26 \\
\hline 26 & & $\begin{array}{l}\text { In total, } 53.6 \% \text { of these informal } \\
\text { settlers had sedentary lifestyles }\end{array}$ & $\begin{array}{l}\text { In total, } 15.4 \% \text { had } \\
\text { tobacco use and } 19.5 \% \text { had } \\
\text { alcohol consumption }\end{array}$ & 28 \\
\hline 28 & & $\begin{array}{l}\text { Overall, } 21.9 \% \text { of men and } 39.4 \% \text { of } \\
\text { women did no physical activities }\end{array}$ & $\begin{array}{l}\text { Overall, } 58 \% \text { of men, } \\
24.9 \% \text { of women, and } \\
38.5 \% \text { of both genders had } \\
\text { alcohol consumption; } \\
51.9 \% \text { of men, } 24.1 \% \text { of } \\
\text { women, and } 35.6 \% \text { of both } \\
\text { genders were smoking }\end{array}$ & 29 \\
\hline 39 & $\begin{array}{l}\text { Lack of dietary diversity among residents } \\
\text { of informal settlements }(58.1 \%) \text { which } \\
\text { significantly differed from that in } \\
\text { residents of formal settlements }(15.4 \%)\end{array}$ & & & 23 \\
\hline 34 & $\begin{array}{l}\text { Fifty-one percent of female informal } \\
\text { settlers and } 53 \% \text { of urban women had } \\
\text { normal nutritional status }\end{array}$ & & & 29 \\
\hline 40 & Residents in such neighborhoods did not & & & 29 \\
\hline
\end{tabular}




\begin{tabular}{|c|c|c|c|}
\hline & $\begin{array}{l}\text { have easy access to food security and } \\
\text { nutritional health; consumption of staples } \\
\text { such as meat, dairy products, vegetables } \\
\text { and fruit were at a low level, and more } \\
\text { than } 27 \% \text { of them had no access to the } \\
\text { original source of protein i.e. meat }\end{array}$ & & \\
\hline 27 & $\begin{array}{l}\text { All the individuals were taking rice and } \\
\text { vegetables every day but less than } 20 \% \text { of } \\
\text { them had daily protein consumption }\end{array}$ & & 22 \\
\hline 36 & $\begin{array}{l}\text { Forty-four percent of individuals took } \\
\text { lower levels of energy than the daily } \\
\text { amount recommended }\end{array}$ & $\begin{array}{l}\text { Seventeen percent of women were } \\
\text { inactive in terms of physical activities }\end{array}$ & 28 \\
\hline 37 & & $\begin{array}{l}\text { In total, } 26.1 \% \text { of these individuals } \\
\text { received low scores and } 47 \% \text { obtained } \\
\text { high scores in terms of physical } \\
\text { activities }\end{array}$ & 29 \\
\hline 29 & $\begin{array}{l}\text { A very high proportion of the three groups } \\
\text { had received inadequate fruit and } \\
\text { vegetables (men in urban areas }=6.3 \% \text {, } \\
\text { men in informal settlements }=7.7 \% \text {, men in } \\
\text { rural areas }=8.1 \% \text {, women in urban } \\
\text { areas }=10.5 \% \text {, women in informal } \\
\text { settlements }=13.3 \% \text {, and women in rural } \\
\text { areas }=20.2 \% \text { ) }\end{array}$ & $\begin{array}{l}\text { In total, } 77.4 \% \text { of rural men, } 65.9 \% \text { of } \\
\text { men living in informal settlements, } \\
\text { and } 57.4 \% \text { of urban men did enough } \\
\text { physical activities; such values in rural } \\
\text { and urban women were } 55.1 \% \text { and } \\
22.9 \% \text {, respectively; } 27.3 \% \text { of women } \\
\text { in informal settlements also did } \\
\text { adequate physical activities }\end{array}$ & 28 \\
\hline 38 & & $\begin{array}{l}\text { Only } 39 \% \text { of informal settlers did } \\
\text { enough physical activities }\end{array}$ & 25 \\
\hline 65 & $\begin{array}{l}\text { Sixty percent of daily energy was obtained } \\
\text { from carbohydrates, } 12-13 \% \text { from } \\
\text { proteins, and } 24-27 \% \text { from fats }\end{array}$ & & 27 \\
\hline
\end{tabular}

\section{Discussion}

Lifestyle is characterized with numerous indicators including nutrition, physical activities, leisure time activities, sleeping habits, social relationships, family relationships, spirituality, security and relaxation $(2,4)$. According to this review of studies on different dimensions of lifestyles among informal settlers, the findings revealed limited investigations in this respect. Thus; the purpose of the present study was to gain knowledge and insight in terms of lifestyle in informal settlements. But as stated, the majority of the studies had only shed light on some dimensions of lifestyles which are discussed below. Nutritional status (foodstuff, BMI), physical activity, leisure time, as well as smoking and alcohol consumption were considered as dimensions of informal settlers' lifestyles addressed in the studies reviewed. The results of studies on nutritional status suggested improper food diversity $(34,39)$ and inadequate food intake among informal settlers (27). The highest proportion of their energy was also obtained from carbohydrates and the lowest part was supplied with protein groups $(27,40)$. In their daily diet, salt intake was reported to be more than five grams $(26,31)$. Moreover, consumption of fruit and vegetables $(26,28,40)$ as well as dairy products was insufficient (40). However, it should be noted that dietary variety is essential to ensure adequate intake of nutrients. Food diversity can be likewise used as an instrument to evaluate diet quality as well as household food security (41). Lack of dietary diversity can be accompanied by cardiovascular diseases and increased risks of metabolic syndrome (42). As a result, populations in informal settlements with a low-variety diet and the resulting lack of nutrients are vulnerable groups to malnutrition and associated diseases. For example; in a nationwide study in southern Africa, the results demonstrated improper food variety among residents in informal neighborhoods (43). In this respect, the high costs of healthy foods lead the poor towards high-energy but low-quality and inexpensive foodstuff (44). In this regard, research studies have shown that low-calorie, nutritious, and less processed foods such as fruit and vegetables are generally more expensive, and their costs are as a barrier to access them among urban poor people (45-47). As a result, implementation of health promotion strategies to improve dietary diversity will not be effective by itself in these areas and it is recommended, especially when the majority of the target population is comprised of low-income individuals, to analyze and determine the dietary needs carefully. Overcoming obstacles in this respect requires a whole range of responses including efforts to reduce food prices, which simultaneously needs government intervention to supply food through taxes and subsidies. Another strategy in this line is to ensure healthy food choices in the individual's food pyramid plan (48). Another dimension of lifestyle is weight control. Malnutrition has been reported to a large extent among informal settlers in the form of weight loss, overweight, and 
obesity. The rate of underweight in informal settlers is reported to be more than that of the urban population. In the study conducted by Gaur et al. on women residing in mega-cities in India, 19\% of urban women and $24 \%$ of women living in informal settlements were underweight (34). As a result, human rights-based programs are required to guarantee the elimination of hunger, and minimize the adverse impacts of urban poverty on nutritional health and development of organizations as well as laws and regulations to help the poor economically. The problem of overweight and obesity was also noticeable and pervasive among informal settlers, in a way that the review of the given studies showed the frequency of overweight (BMI: $25-29.9 \mathrm{~kg} / \mathrm{m}^{2}$ ) varying from $4.21 \%$ to $32.5 \%(30,49)$, such a frequency of obesity (BMI: $30-34.9 \mathrm{~kg} / \mathrm{m}^{2}$ ) was from $1.9 \%$ to $75 \%(29,31)$, and the prevalence rate of abdominal obesity varied from $10 \%$ to $57.1 \%(30,32)$. Research showed that nutritional deficiencies continue as a concern. Investigations in various countries have similarly confirmed the relationship between poverty and overweight in a way that a rise in obesity has been reported in groups with lower economic status (50-51). Food insecurity due to widespread urban poverty, as easily as it can lead to malnutrition, can also lead to overweight and obesity. (44). Genetic factors, increasing more energy intake than consumption, sedentary lifestyle, environmental, social and psychological factors, neurological disorders and excessive nutrition in childhood are factors that contribute to obesity (52-53). Lifestyle is the most important factor associated with obesity (54). Due to the massive expansion of overweight in society, its prevention and treatment has become a public health priority (55). Thus; according to statistics on malnutrition in the form of underweight or overweight, it is required to have planning for urban nutrition which can affect diets and behavioral changes.

Physical activity is also considered as one of the key factors in maintaining a healthy lifestyle and preventing overweight (56). In terms of physical activity, most informal settlers experience a lifestyle deprived of sports. Inadequate physical activity was also confirmed in the majority of studies reviewed. Statistics reported in most studies, indicated that less than $10 \%$ of informal settlers had enough exercises $(30-31,35)$ and $50-93 \%$ of them did not have enough physical activities in their weekly schedule (30-31,35). According to the results of an investigation by Gore and Mangala on slum dwellers in Bangalore, $84.4 \%$ of individuals had a sedentary lifestyle, $13.4 \%$ of such individuals did light exercises, and $1.8 \%$ of them did moderate levels of physical activities (31). In the study by Taka and Tragler in Mumbai, only 7.9\% of informal settlers experienced sports in their lifestyle, and $92.1 \%$ of them did not do any physical activities (30). In the study by Rajabi Gilan et al. in Kermanshah, 29.2\% of women residing in informal neighborhoods had no physical activities. The low, moderate, and high levels of physical activities among these individuals were $35.5 \%, 18.4 \%$, and $2.2 \%$; respectively (35). The importance of physical activity in the prevention of diseases is also well-known. Despite the fact that physical activity is accessible to everyone, it is estimated that $60 \%$ of adults and $43 \%$ of the global burden of diseases is associated with physical activity (38). Such investigations showed the importance of socio-economic conditions and place of living on the levels of physical activities. Higher socioeconomic levels were likewise associated with better levels doing sports and exercises (5758). As a policy, it is recommended to develop urban infrastructure facilitating fun activities such as hiking and biking, provide sport facilities to citizens, and encourage use of non-motorized transportation. Since women are more deprived than men in terms of using urban facilities, the given policies should be gender-sensitive and target them specifically (29). According to the results of studies reviewed, the prevalence rate of smoking in male informal settlers was between $34 \%$ and $51.9 \%(28,32)$ and higher than that in women $(1.4-24.9 \%)(28,35)$. The same trend was also seen in terms of alcohol consumption in a way that the intake rate among men was $35-58 \%$ and higher than that in women $(4-24.9 \%)(28,32)$. In the study by Oli et al. in Nepal, $58 \%$ of men, $24.9 \%$ of women, and $38.5 \%$ of both genders had alcohol consumption. In this respect, $51.9 \%$ of men, $24.1 \%$ of women, $35.6 \%$ of both genders had tobacco use (28). Furthermore; the results of a study by Rajabi Gilan et al. (2014) in Kermanshah showed that $1.4 \%$ of women residing in informal neighborhoods were smoking (35). Numerous studies have also indicated that excessive alcohol and tobacco consumption was accompanied by a series of adverse social, economic, health-related consequences for society (59-61). Thus, it is necessary to consider mechanisms leading to the use of these substances, and develop programs for the prevention of their consumption and complications. In the study by Darvishi (2014) in Ardabil, causes of addiction among informal settlers were introduced as geographical conditions of informal neighborhoods (high population density, possibility of hiding criminals, lower levels of social control, and lack of recreational sites), easy distribution of drugs and security provided to drug dealers, increased tendency to use drugs (due to unemployment and low education level), unemployment, and economic poverty leading individuals to drug trafficking, lack of recreational and leisure time facilities, cultural poverty, low levels of literacy, lack of social justice, and gaps between social classes (62). Given the specific causes of addiction in informal settlements as well as its high prevalence rate, it is necessary to identify and determine associated controlling solutions. 
Considering the high statistics in terms of populations of informal settlers in many countries in the world, and the limited number of studies on health status and lifestyles among them, further investigations are recommended in this respect to have a precise identification of upcoming problems and challenges, and provide solutions. Thus, a good understanding of this situation can lead to taking preventive measures and improving lifestyles with minimal negative consequences in terms of health. The present study had several limitations including: 1) lack of access to all unpublished research papers and reports, 2) limited scope of the studies conducted in this respect on all dimensions of lifestyle, and 3) inability in comparison and analysis of the results of studies due to small number of studies and differences in sample size.

\section{Conclusions}

As a whole, this review showed that unhealthy lifestyle is common among individuals living in informal settlements. There was no food diversity. Malnutrition was common, especially overweight. The majority of them did not have enough physical activity, and smoking and alcohol consumption were common. Therefore, to improve the situation of the suburban population, developing an urban infrastructure that facilitates recreational activities (such as walking and cycling), providing sports facilities, encouraging the use of non-motorized vehicles, developing programs for prevention of smoking, improvement of health, increasing employment opportunities, and nutritional aid for vulnerable groups are recommended.

\section{Acknowledgments:}

The paper is taken from $\mathrm{PhD}$ Thesis of reproductive health International Branch Shahid Beheshti University of Medical Sciences, Tehran, Iran (code: IR.SBMU.RETECH.REC.1395.244, Date of Approval: 2016/7/18). The authors thank the faculty officials and employees of Shahid Beheshti University of Medical Sciences.

\section{Conflict of Interest:}

There is no conflict of interest to be declared.

\section{Authors' contributions:}

All authors contributed to this project and article equally. All authors read and approved the final manuscript.

\section{References:}

1) Shamsoddini A, Shojaee S. Assessing the factors affecting lifestyle of rural women in Iran: a case study in Fahimiyan village-Mamasani area. JBES. 2015; 6(1): 670-5.

2) Lali M, Abedi A, Kajbaf M. Construction and Validation of the Lifestyle Questionnaire (LSQ). Psychological research. 2012; 15(1): 64-80.

3) Bavil DA, Dolatian M, Mahmoodi Z, Baghban AA. Comparison of lifestyles of young women with and without primary dysmenorrhea. Electron physician. 2016; 8(3): 2107-14. doi: 10.19082/2107. PMID: 27123219, PMCID: PMC4844476.

4) Mahmoodi Z, Karimlou M, Sajjadi H, Dejman M, Vameghi M. Using social determinants of health to prevent disability by laying emphasis on maternal lifestyle during pregnancy. MEJDS. 2013; 3(1): 62-73.

5) Khosrorad T, Dolatian M, Riazi H, Mahmoodi Z, Alavimajd H, Shahsavari S, et al. Comparison of lifestyle in fertile and infertile couples in Kermanshah during 2013. Iran J Reprod Med. 2015; 13(9): 549-56. PMID: 26568759, PMCID: PMC4637122.

6) Mansoorian M, Qorbani M, Shafieyan N, Asayesh H, Shafieyan Z, Maghsodloo D. Association between life style and hypertension in rural population of Gorgan. JHPM. 2012; 1(2): 23-8.

7) Samiei Siboni F, Alimoradi Z, Sadegi T. Impact of corrective life style educational program on controlling stress, anxiety, and depression in hypertensives. J Birjand Univ Med Sci. 2013; 19(6): 1-9.

8) Jamshidi A, Jamini D, Jamshidi M, Cheraghi R. Informal settlement, prioritizing the neighborhood challenges of Jafar Abad of Kermanshah. Human Geography Research Quarterly. 2013; 45(4): 221-42.

9) Department of Health. Provide and promote primary health care program in the form of expanding and strengthening the health network in urban areas version 3. 2015.

10) Shibani Amin A, Gholami M. Informal settlements, causes, consequences and solutions case study: Shirabad Zahedan. 3rd urban planning and Management Conference. 2011.

11) Ameratunga $S$, Hijar M, Norton R. Road-traffic injuries: confronting disparities to address a global-health problem. Lancet. 2006; 367(9521): 1533-40. doi: 10.1016/S0140-6736(06)68654-6. PMID: 16679167. 
12) Burnes D, Pillemer K, Caccamise PL, Mason A, Henderson CR, Berman J, et al. Prevalence of and Risk Factors for Elder Abuse and Neglect in the Community: A Population-Based Study. J Am Geriatr Soc. 2015; 63(9): 1906-12. doi: 10.1111/jgs.13601. PMID: 26312573.

13) Berube A. Updating the war on poverty for a suburban age. Innovating to End Urban Poverty conference. 2014.

14) Sverdlik A. Ill-health and poverty: a literature review on health in informal settlements. Environ Urban. 2011; 23(1): 123-55. doi: 10.1177/0956247811398604.

15) Kaufman Z, Braunschweig E, Feeney J, Dringus S, Weiss H, Delany-Moretlwe S, et al. Sexual Risk behavior, alcohol use, and social media use among secondary school students in informal settlements in Cape Town and Port Elizabeth, South Africa. AIDS Behav. 2014; 18(9): 1661-74. doi: 10.1007/s10461014-0816-x. PMID: 24934651.

16) Beguy D, Elung'ata P, Mberu B, Oduor C, Wamukoya M, Nganyi B, et al. Health \& Demographic Surveillance System Profile: The Nairobi Urban Health and Demographic Surveillance System (NUHDSS). Int J Epidemiol. 2015; 44(2): 462-71. doi: 10.1093/ije/dyu251. PMID: 25596586.

17) Snyder RE, Jaimes G, Riley LW, Faerstein E, Corburn J. A comparison of social and spatial determinants of health between formal and informal settlements in a large metropolitan setting in Brazil. J Urban Health. 2014; 91(3): 432-45. doi: 10.1007/s11524-013-9848-1. PMID: 24297475, PMCID: PMC4074326.

18) Nay O, Béjean S, Benamouzig D, Bergeron H, Castel P, Ventelou B. Achieving universal health coverage in France: policy reforms and the challenge of inequalities. Lancet. 2016; 387(10034): 2236-49. doi: 10.1016/S0140-6736(16)00580-8. PMID: 27145707.

19) Mazurek Melnyk B, Slevin C, Militello L, Hoying J, Teall A, McGovern C. Physical health, lifestyle beliefs and behaviors, and mental health of entering graduate health professional students: Evidence to support screening and early intervention. J Am Assoc Nurse Pract. 2016; 28(4): 204-11. doi: 10.1002/23276924.12350. PMID: 26990269.

20) Zayari k, Rafiee Mehr H. Factors affecting the quality of life of residents of informal areas. Human Geography Research Quarterly. 2015; 47(1): 21-32.

21) Bagheri M, Moltafet H. Factors affecting women's crime: study examples of women in Ahvaz. JISDS. 2010; 4(10): 163-77.

22) Özener B, Fink B. Facial symmetry in young girls and boys from a slum and a control area of Ankara, Turkey. Evol Hum Behav. 2010; 31(6): 436-41. doi: 10.1016/j.evolhumbehav.2010.06.003.

23) Moher D, Shamseer L, Clarke M, Ghersi D, Liberati A, Petticrew M, et al. Preferred reporting items for systematic review and meta-analysis protocols (PRISMA-P) 2015 statement. Syst Rev. 2015; 4: 1. doi: 10.1186/2046-4053-4-1. PMID: 25554246, PMCID: PMC4320440.

24) Shamseer L, Moher D, Clarke M, Ghersi D, Liberati A, Petticrew M, et al. Preferred reporting items for systematic review and meta-analysis protocols (PRISMA-P) 2015: elaboration and explanation. BMJ. 2015; 349: g7647. doi: 10.1136/bmj.g7647. PMID: 25555855.

25) Von Elm E, Altman DG, Egger M, Pocock SJ, Gøtzsche PC, Vandenbroucke JP. The Strengthening the Reporting of Observational Studies in Epidemiology [STROBE] statement: guidelines for reporting observational studies. BMJ. 2007; 335(7624): 806-8. doi: 10.1136/bmj.39335.541782.AD. PMID: 17947786, PMCID: PMC2034723.

26) Nirmala Devi B, Vijay Kumar M, Sreedhar M. Prevalence of risk factors for Non Communicable Diseases in urban slums of Hyderabad, Telangana. IJBAMR. 2014; 4(1): 487-93.

27) Kiranmai K, Saritha V, Mallika G, Lakshmi NV. Assessment of health status of women in urban slum. Indian Journal of Innovations and Developments. 2012; 1(4): 220-4.

28) Oli N, Vaidya A, Thapa G. Behavioural risk factors of noncommunicable diseases among Nepalese urban poor: A descriptive study from a slum area of Kathmandu. Epidemiol Res Int. 2013; 2013. doi: $10.1155 / 2013 / 329156$.

29) Yadav K, Krishnan A. Changing patterns of diet, physical activity and obesity among urban, rural and slum populations in north India. Obes Rev. 2008; 9(5): 400-8. doi: 10.1111/j.1467-789X.2008.00505.x. PMID: 18627500.

30) Taka T, Tragler A. Prevalence of Obesity and the Factors Influencing it among Women in a Slum of Mumbai. IOSR-JDMS. 2014; 13(4): 76-9. doi: 10.9790/0853-13447679.

31) Gore Chaitali A, Mangala S. A study on hypertension in an urban slum in bangalore, india. IJMAS. 2015; 4(2): 78-83. 
32) Heitzinger K, Montano SM, Hawes SE, Alarcón JO, Zunt JR. A community-based cluster randomized survey of noncommunicable disease and risk factors in a peri-urban shantytown in Lima, Peru. BMC Int Health Hum Rights. 2014; 14(1): 1. doi: 10.1186/1472-698X-14-19.

33) Ettarh R, Van de Vijver S, Oti S, Kyobutungi C. Overweight, obesity, and perception of body image among slum residents in Nairobi, Kenya, 2008-2009. Prev Chronic Dis. 2013; 10: E212. doi: 10.5888/pcd10.130198. PMID: 24355105, PMCID: PMC3869529.

34) Gaur K, Keshri K, Joe W. Does living in slums or non-slums influence women's nutritional status? Evidence from Indian mega-cities. Soc Sci Med. 2013; 77: 137-46. doi: 10.1016/j.socscimed.2012.11.017. PMID: 23219849.

35) Rajabi Gilan N, Ghasemi S, Reshadat S, Zanganeh S, Saedi S. Measurement quality of life associated with the health of women in the marginal slums of Kermanshah and Some factors associated with it. J Kermanshah Univ Med Sci. 2014; 18(9): 547-56.

36) Alves JG, Falcão RW, Pinto RA, Correia JB. Obesity patterns among women in a slum area in Brazil. J Health Popul Nutr. 2011; 29(3): 286-9. PMID: 21766564, PMCID: PMC3131129.

37) Alves JGB, Figueiroa JN, Alves LV. Prevalence and predictors of physical inactivity in a slum in Brazil. J Urban Health. 2011; 88(1): 168-75. doi: 10.1007/s11524-010-9531-8. PMID: 21274645, PMCID: PMC3042091.

38) Anderson GS, Snodgrass J, Elliott B. Determining physical activity patterns of suburban British Columbia residents. Can J Public Health. 2007; 98(1): 70-3. PMID: 17278682.

39) Drimie S, Faber M, Vearey J, Nunez L. Dietary diversity of formal and informal residents in Johannesburg, South Africa. BMC public health. 2013; 13(1): 1. doi: 10.1186/1471-2458-13-911.

40) Hatami Nejad H, Mehdi A, Mahdian Bahnamiri M. Evaluate the health of residents living in marginal neighborhoods in aspects of food security and nutritional health (Case Study: Shadqly Khan Neighborhood Qom). Quarterly Journal of Human Geography. 2013; 5(2): 53-72.

41) Faber M, Schwabe C, Drimie S. Dietary diversity in relation to other household food security indicators. Int J Food Safety, Nutrition and Public Health . 2009; 2(1): 1-15. doi: 10.1504/IJFSNPH.2009.026915.

42) Mehrabani S, Mohammadifard N, Mehrabani S, Sadeghi M, Sajjadi F, Maghroun M, et al. The Effect of Nutrition Consultation on Dietary Diversity Score of Cardiac Patients Referred to Cardiac Rehabilitation Research Center Isfahan Cardiovascular Research Institute during 2008-2013. Int J Prev Med. 2016; 7: 121. doi: 10.4103/2008-7802.193464. PMID: 27994822, PMCID: PMC5139448.

43) Labadarios D, Steyn NP, Nel J. How diverse is the diet of adult South Africans? Nutr J. 2011; 10: 33. doi: 10.1186/1475-2891-10-33. PMID: 21496326, PMCID: PMC3094278.

44) Kearney J. Food consumption trends and drivers. Philos Trans R Soc Lond B Biol Sci. 2010; 365(1554): 2793-807. doi: 10.1098/rstb.2010.0149. PMID: 20713385, PMCID: PMC2935122.

45) Schonfeldt HC, Gibson N, Vermeulen H. The Possible Impact of Inflation on Nutritionally Vulnerable Households in a Developing Country using South Africa as a Case Study. Nutr Bull. 2010; 35: 254-67. doi: 10.1111/j.1467-3010.2010.01837.x.

46) Brinkman HJ, de Pee S, Sanogo I, Subran L, Bloem MW. High food prices and the global financial crisis have reduced access to nutritious food and worsened nutritional status and health. J Nutr. 2010; 140(1): 153-61. doi: 10.3945/jn.109.110767. PMID: 19939996.

47) Faber M, Laubscher R, Laurie S. Availability of, access to and consumption of fruits and vegetables in a peri - urban area in KwaZulu - Natal, South Africa. Matern Child Nutr. 2013; 9(3): 409-24. doi: 10.1111/j.1740-8709.2011.00372.x. PMID: 22188599.

48) Oldewage Theron WH, Kruger R. Impact of food aid on food variety and dietary diversity of an elderly community in Sharpville, South Africa. J Nutr Health Aging. 2009; 13(4): 300-8. doi: 10.1007/s12603-0090027-8. PMID: 19300864.

49) Haque M, Bhuiyan M, Naser M, Arafat $Y$, Suman K. Nutritional status of women dwelling in urban slum area. J Nutr Health Food Eng. 2014; 1(3): 1-14. doi: 10.15406/jnhfe.2014.01.00014.

50) Hernandez DC, Pressler E. Accumulation of childhood poverty on young adult overweight or obese status: race/ethnicity and gender disparities. J Epidemiol Community Health. 2014; 68(5): 478-84. doi: 10.1136/jech-2013-203062. PMID: 24391207.

51) Lee H, Andrew M, Gebremariam A, Lumeng JC, Lee JM. Longitudinal associations between poverty and obesity from birth through adolescence. Am J Public Health. 2014; 104(5): e70-e6. doi: 10.2105/AJPH.2013.301806. PMID: 24625156, PMCID: PMC3987582. 
52) Williams EP, Mesidor M, Winters K, Dubbert PM, Wyatt SB. Overweight and obesity: prevalence, consequences, and causes of a growing public health problem. Curr Obes Rep. 2015; 4(3): 363-70. doi: 10.1007/s13679-015-0169-4. PMID: 26627494.

53) Weiss S. Contributing Factors of Obesity Among Over-the-Road Truckers. Doctor of Philosophy Public Health theses. Walden University; 2017.

54) Sadat Zahedi H, Jafari Adli S, Hasani Ranjbar S. Pathogenesis, etiology and complications associated with obesity. IJDO. 2013; 12(5): 375-92.

55) Wang H1, Zhai F. Program and Policy Options for Preventing Obesity in China. Obes Rev. 2013; 14(2): 134-40. doi: 10.1111/obr.12106. PMID: 24102781, PMCID: PMC4048452.

56) Vafadar Z, Reazei R, Navidian A. Effectiveness of motivational interviewing on the weight self-efficacy life style in overweight and obese teenager boys. International Journal of Behavioral Sciences. 2014; 8(2): 21-22.

57) Andrade AC, Peixoto SV, Friche AA, Goston JL, César CC, Xavier CC, et al. Social context of neighborhood and socioeconomic status on leisure-time physical activity in a Brazilian urban center: The BH Health Study. Cad Saude Publica. 2015; 31: 136-47. doi: 10.1590/0102-311X00069514. PMID: 26648369.

58) Van Holle V, Van Cauwenberg J, Van Dyck D, Deforche B, Van de Weghe N, De Bourdeaudhuij I. Relationship between neighborhood walkability and older adults' physical activity: results from the Belgian Environmental Physical Activity Study in Seniors (BEPAS Seniors). Int J Behav Nutr Phys Act. 2014; 11: 110. doi: 10.1186/s12966-014-0110-3. PMID: 25148845, PMCID: PMC4145228.

59) Lange C, Manz K, Rommel A, Schienkiewitz A, Mensink G. Alcohol consumption of adults in Germany: Harmful drinking quantities, consequences and measures. Journal of Health Monitoring. 2016; 1(1): 1-20. doi: 10.17886/RKI-GBE-2016-029.

60) Marshall EJ. Adolescent alcohol use: risks and consequences. Alcohol Alcohol. 2014; 49(2): 160-4. doi: 10.1093/alcalc/agt180. PMID: 24402246.

61) World Health Organization. Global status report on alcohol and health 2014. World Health Organization; 2014.

62) Darvishi Y. Marginalization and its role in the occurrence and spread of drugs and addiction (Case study: Ardebil). Human Geography Research Quarterly. 2014; 46(3): 603-14.

63) Ahaneku G, Osuji C, Oguejiofor O, Anisiuba B, Ikeh V, Ahaneku J. Blood Pressure and Obesity Index Assessment in a Typical Urban Slum in Enugu, Nigeria. East Afr Med J. 2015; 92(4): 170-7.

64) Ghasemi SR, Gilan NR, Reshadat S, Tavangar F, Saedi S, Soofi M. Quality of Leisure Time in Women Resident in Marginal Neighborhoods and its Relation with Health Related Quality of Life. J Mazandaran Univ Med Sci. 2015; 24(120).

65) Misra A, Sharma R, Pandey R, Khanna N. Adverse profile of dietary nutrients, anthropometry and lipids in urban slum dwellers of northern India. Eur J Clin Nutr. 2001; 55(9): 727-34. doi: 10.1038/sj.ejcn.1601214. PMID: 11528485 . 